\title{
Immunocytochemistry of Band 3 Protein in Kidney and Other Tissues of Control and Cystic Fibrosis Patients
}

\author{
D. J. HAZEN-MARTIN, G. PASTERNACK, R. A. HENNIGAR, S. S. SPICER, AND D. A. SENS \\ Departments of Pathology, Medical University of South Carolina, Charleston, South Carolina 29425 and Johns \\ Hopkins University, Baltimore, Maryland 21205
}

\begin{abstract}
Current evidence indicates that the underlying genetic defect in cystic fibrosis (CF) results in defective chloride transport, and more specifically, chloride impermeability. However, recent consideration has been given to a possible defect in band 3 protein at $\mathrm{CF}$-affected sites. In an effort to determine a possible role for band 3 , an anion exchange channel protein, a series of immunocytochemical localizations was performed. Immunocytochemical staining for the anion channel band $3,43 \mathrm{~K}$, in normal and CF human kidney was confined to erythrocytes, glomerular podocytes, the basal region of half of the cells of the initial connecting segment of cortical collecting ducts, and a minority of cells in medullary ray-collecting ducts. Erythrocytes alone evidenced immunoreactivity for band 3 protein in human pancreas, submandibular gland, trachea, and lung. In all cases, specimens from patients with $\mathrm{CF}$ stained like those from control subjects for band 3 . Abnormal $\mathrm{Cl}^{-}$transport in CF tissues is not reflected in altered band 3, 43K, localizations. (Pediatr Res 21: 235-237, 1987)
\end{abstract}

\section{Abbreviations}

CF, cystic fibrosis

PBS, phosphate-buffered saline

SDS, sodium dodecyl sulfate

SDS-PAGE, SDS-polyacrylamide gel

electrophoresis

Stemming from the diagnostically elevated $\mathrm{Na}^{+}$and $\mathrm{Cl}^{-}$in $\mathrm{CF}$ sweat (1), the perception has emerged of deficient ion transport $(2-5)$ and more specifically altered $\mathrm{Cl}^{-}$permeability $(3,5)$ as the underlying genetic defect in this disease. Altered chloride transport in turn has prompted the consideration of the presence and/ or abnormality of a band 3-mediated anion exchange in CFaffected tissues. In erythrocytes the band 3 anion channel facilitates rapid $\mathrm{Cl}^{-} / \mathrm{HCO}^{-}$exchange where it makes up $25 \%$ of the total membrane protein of these cells (6). An effort was undertaken accordingly to localize band 3 protein immunocytochemically in sites of active ion transport with the aim of first determining whether sites affected in CF correspond with sites immunoreactive for band 3 protein and, second, comparing band 3-positive sites in normal and CF specimens.

Received April I, 1986; accepted October 14, 1986.

Correspondence and reprint requests D. J. Hazen-Martin, Ph.D., Division of Cellular Biopathology, Department of Pathology, Medical University of South Carolina, 171 Ashley Avenue, Charleston, SC 29425.

Supported by NIH Grant AM 11028.

\section{MATERIALS AND METHODS}

Band 3 cytoplasmic domain ( $43 K$ ) purification. Band 3 cytoplasmic domain $(43 \mathrm{~K})$ was isolated from whole human blood. After spectrin extraction (7) and extraction of ankyrin and protein $4.1(8,9)$, the cytoplasmic domain of band 3 was prepared from the high salt-extracted vesicles as described (10) by cleavage with $\alpha$ chymotrypsin, followed by chromatography on DEAEcellulose (Watman, Clifton, $\mathrm{NJ}$ ) and gel filtration on ultragel AcA 44 resin (LKB, Rockville, MD). Materials prepared by this method are referred to as $43 \mathrm{~K}$ peptides, although such preparations appear more heterogeneous on SDS gels. Immunologic criteria described previously (10) demonstrated that the smaller peptides were derived from the dominant $43 \mathrm{~K}$ product. In all purifications, fractions were analyzed by SDS-PAGE on $10 \%$ gels (11) and purified pools were concentrated by vacuum dialysis against $130 \mathrm{mM} \mathrm{KCl}, 20 \mathrm{~mm} \mathrm{NaCl}, 10 \mathrm{mM}$ Tris- $\mathrm{HCl}, \mathrm{pH} 7.5$, with $1 \mathrm{mM}$ EDTA and $1 \mathrm{mM} \mathrm{NaN}_{3}$. Protein concentrations were determined by the methods of Lowry et al. (12) using bovine serum albumin standards. This method has been determined by amino acid analysis to reflect accurately the true protein concentration (13).

Antisera preparations. Sheep antiband 3 was generously provided by Dr. Vincent Marchesi and was prepared as described (14). This antiserum was prepared against the whole band 3 protein and was shown to react primarily with the cytoplasmic domain that is referred to as $43 \mathrm{~K}$. Rabbit anti-43K was prepared by immunizing a $7-\mathrm{kg}$ New Zealand White female rabbit with $100 \mu \mathrm{g}$ of $43 \mathrm{~K}$ divided among sites in each hindquarter and each shoulder. For primary immunization the protein was diluted to $200 \mathrm{~g} / \mathrm{ml}$ in PBS, then diluted $1: 1$ in complete Freund's adjuvant (Difco, Detroit, MI) which was mixed until a stable emulsion was formed. After intramuscular administration, the animal was boosted at $2 \mathrm{wk}$ with $100 \mu \mathrm{g}$ of antigen in incomplete Freund's adjuvant. Two weeks after boosting, the animal was bled from the ear veins, and the serum was tested for activity by an enzymelinked immunosorbent assay using horseradish peroxidase-conjugated protein A. For subsequent bleedings, the rabbit was boosted as described, then bled 2 wk later.

Affinity purification of anti-43K antibodies. Rabbit anti-43K antibodies and sheep antiband 3 antibodies were affinity purified by passing the antisera through a $43 \mathrm{~K}$-Sepharose column as described (13). Briefly, 43K was conjugated to Sepharose CL-4B (Pharmacia, Piscataway, NJ) activated with $\mathrm{CNBr}$ (15). The column was washed with $300 \mathrm{mM} \mathrm{NaCl}, 100 \mathrm{mM}$ Tris- $\mathrm{HCl}, 1$ $\mathrm{mM} \mathrm{NaN}_{3}$ at $\mathrm{pH} 7.4$, and eluted with the same buffer containing $6 \mathrm{M}$ urea. The eluted antibody was concentrated by vacuum dialysis against PBS; some samples were lyophilized after concentration. Different lots of $43 \mathrm{~K}$ were used to prepare the affinity column, to immunize, and to perform the inhibitions with antigen. 
Tissue preparation. Human tissues were obtained from autopsies performed less than $6 \mathrm{~h}$ postmortem. Surgical specimens were also utilized and consisted of either normal tissues adjacent to tumors or organs prepared, but not used, for transplantation. The acquisition and use of human tissue was approved by the Internal Review Board for Human Research of the Medical University of South Carolina. Specimens of pancreas, submandibular gland, kidney, trachea, and lung were obtained from six $\mathrm{CF}$ patients and seven non-CF controls. Tissues were fixed $24 \mathrm{~h}$ at $4^{\circ} \mathrm{C}$ in Carnoy fixative and processed routinely into paraffin. Preliminary studies indicated that Carnoy fixative was superior to other routine fixatives in preserving the immunoreactivity of band 3 protein in human tissues.

Immunocytochemistry. Sections from all specimens were rehydrated and treated with 3\% hydrogen peroxide to eliminate endogenous peroxidase activity prior to overnight exposure at $4^{\circ} \mathrm{C}$ to the band 3 antibody diluted over a range of 20 to $200 \mu \mathrm{g} /$ $\mathrm{ml}$ to achieve an optimal concentration. Sections of kidney serial to those stained for band 3 were stained similarly with commercial antisera to Tamm-Horsfall protein (Cooper Biomedical, Inc., Malvern, PA) and human epidermal keratin (Dako Laboratories, Westbury, NY) to identify renal segments with band 3 reactive cells. To visualize sites of antibody binding, the Vectastain ABCHRP Kit (Vector Laboratories, Inc., Burlingame, $C A$ ) was employed (16). Sections were incubated with a DAB- $\mathrm{H}_{2} \mathrm{O}_{2}$ substrate, dehydrated, and mounted for viewing. Controls consisted of substituting the primary antibody in the staining sequence with either affinity purified IgG from a nonimmune rabbit or the specific band 3 antibody dilution absorbed with a second band 3 protein preparation for $24 \mathrm{~h}$ at $4^{\circ} \mathrm{C}$.

\section{RESULTS}

Immunoreactivity for band 3 anion channel protein was observed in selected cells in the kidney but was not evident in any cells other than erythrocytes in the submandibular gland, pancreas, trachea, and lung.

In the kidney immunostaining was confined to glomerular podocytes and the cortical collecting tubules. The band 3-reactive segments were identified further by their staining for epidermal keratin but not for Tamm-Horsfall protein in serial sections. Thick ascending limbs, identified by Tamm-Horsfall reactivity, and distal convoluted tubules, characterized as negative for Tamm-Horsfall protein and keratin, lacked band 3 immunoreactivity. Intense immunostaining for band 3 protein was localized in intermittent cells comprising half of the cells lining the initial connecting segment of the cortical collecting tubules (Figs. 1 and 2). Band 3-immunoreactive cells comprised only a small minority of cells in the medullary ray portion of the collecting ducts (Fig. 3) and were seldom observed in the medullary collecting tubules. Patterns and intensity of immunoreactivity were the same in autopsy and surgical specimens.

Podocytes exhibited diffuse cytoplasmic staining (Fig. 1). In contrast, the immunoreactivity in the tubule epithelium appeared restricted mainly to the basal and the basolateral plasmalemma. Erythrocytes in vessels revealed intense membrane surface staining in the kidney.

In the $C F$ specimens, band 3 immunoreactivity was identical to that seen in controls. No difference was discernible between the two groups in the number or location of positive cells or in the intensity or location of their cytological staining (Fig. 4).

Sections exposed to a comparable dilution of antigen-absorbed antibody or affinity purified IgG from nonimmune sera in place of the primary band 3 antibody revealed no immunostaining at these sites. In addition, identical staining patterns were observed using the sheep and rabbit antiband 3 antibodies.

\section{DISCUSSION}

The unaltered pattern of immunostaining observed in $\mathrm{CF}$ kidney and erythrocytes extends previous observations of com-

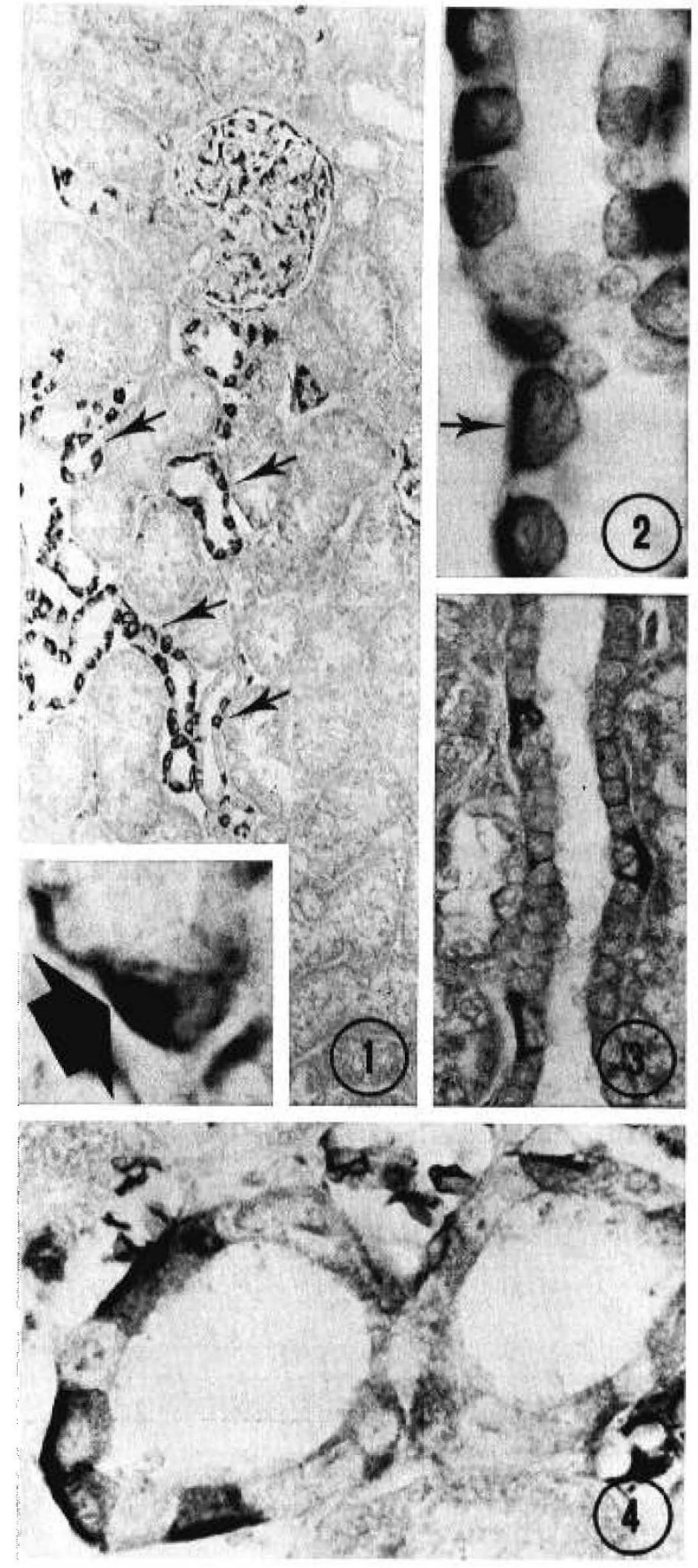

Fig. 1. Immunostaining for band 3 protein in control human kidney cortex is restricted to glomerular podocytes and collecting tubules (arrows). The inset shows immunoreactivity for band 3 in a podocyte (arrow), $\times 180$. Inset $\times 1900$.

Fig. 2. Band 3 protein in the initial (or connecting) segment of normal cortical collecting tubules (arrow) is confined to the basal region of some cells, $\times 900$.

Fig. 3. Band 3 protein in the medullary ray segment of normal collecting ducts is demonstrable in only a few cells, $\times 450$.

Fig. 4. Immunoreactivity for band 3 protein in a collecting tubule from a $\mathrm{CF}$ patient is identical to that observed in control kidneys. Erythrocytes, upper center, stain strongly, $\times 950$. 
parable band 3 immunoreactivity in superficial duct cells of $\mathrm{CF}$ and normal sweat glands (17). These findings do not support a postulated abnormal band 3 protein in CF. While it is possible that an immunologically unaltered but functionally deficient band 3 protein may exist in the CF-affected sites, the present failure to detect band 3 anion channels in primary target sites of pathological change such as lung, pancreas, and salivary glands discredits more conclusively a general band 3 involvement in CF. It seems unlikely that false negatives would be obtained in all of these sites given the strong immunoreactivity in identically and concurrently processed and stained human kidney as reported herein. Stained erythrocytes, moreover, provided a positive control in all specimens.

In this light, the study provides little evidence with which to question reports of $\mathrm{Cl}^{-}$impermeability in CF-affected sites $(3,5)$ and certainly offers no support for the alternative involvement of a neutral anion exchange mechanism in the CF defect. These results are not entirely surprising in view of the lack of either altered chloride transport in erythrocytes (18) or altered function of the kidneys of CF patients, both demonstrated sites of band 3 protein.

The basolateral membrane localization of band 3 protein in select cells of the cortical collecting duct is interesting, however, as it relates to human renal function and the regulation of acid/ base balance. Band 3 anion channels so situated in the collecting duct epithelium could mediate the exchange of serosal $\mathrm{Cl}^{-}$for cytosolic $\mathrm{HCO}_{3}{ }^{-}$, thereby facilitating serosal secretion of $\mathrm{HCO}_{3}{ }^{-}$ generated by cytosolic carbonic anhydrase. Indeed, evidence exists for two types of intercalated cells in the cortical collecting tubule $(20,21)$. One intercalated cell type apparently secretes $\mathrm{H}^{+}$ while the other secretes $\mathrm{HCO}_{3}{ }^{-}$. Basolateral band 3 channels localized in $\mathrm{H}^{+}$-secreting intercalated cells could function to allow the exchange of serosal $\mathrm{Cl}^{-}$for intracellular $\mathrm{HCO}_{3}{ }^{-}$and, therefore, facilitate $\mathrm{HCO}_{3}{ }^{-}$resorption by the kidney cell. A recent report appearing at completion of this study described staining for band 3 protein in intercalated cells of rat renal collecting tubules but not in glomerular podocytes (22). The rat band 3positive cells were identified as intercalated cells by the high density of mitochondria as visualized by antibodies to mitochondrial aldehyde dehydrogenase. Ultrastructural verification of intercalated cell characteristics in the band 3-positive cells of the human kidney will be necessary.

\section{REFERENCES}

1. di Sant'Agnese PA, Darling RC, Perea GA, Shea E 1953 Abnormal electrolyte composition of sweat in cystic fibrosis of the pancreas. Pediatrics 12:549-
563

2. Knowles M, Gatzy J, Boucher R 1981 Increased bioelectric potential difference across respiratory epithelia in cystic fibrosis. N Engl J Med 305:1489-1495

3. Knowles MR, Gatzy JT, Boucher RC 1983 Relative ion permeability of normal and cystic fibrosis nasal epithelium. J Clin Invest 71:1410-1417

4. Patton CJ, Jenkins MQ, Briggman JV, Spicer SS 1982 Amiloride sensitive sodium channels in rectal epithelium of cystic fibrosis patients. Pediatr Res 16:1035-1036

5. Quinton PM 1983 Chloride impermeability in cystic fibrosis. Nature 301:421422

6. Passow H, Fasold H, Zaki L, Schumann B, Lepke S 1985 Membrane proteins and anion exchange in human erythrocytes. In: Gardow G, Szasz I (eds) Biomembranes: Structure and Function. North Holland Publ, Amsterdam, pp 197-214

7. Morrow JS, Speicher DW, Knowles WJ, Hsu CJ, Marchesi VT 1980 Identification of functional domains of human erythrocyte spectrin. Proc Natl Acad Sci USA 77:6592-6596

8. Leto TL, Marchesi VT 1984 A structural model of human erythrocyte protein 4.1. J Biol Chem 259:4603-4608

9. Tyler JM, Hargreaves WR, Branton D 1979 Purification of two spectrinbinding proteins: biochemical and electron microscopic evidence for site specific reassociation between spectrin and bands 2.1 and 4.1. Proc Natl Acad Sci USA 76:5192-5196

10. Bennett V, Stenbuck PJ 1980 Association between ankyrin and the cytoplasmic domain of band 3 isolated from human erythrocyte membrane. J Biol Chem 255:6424-6432

11. Laemmli UK 1970 Cleavage of structural proteins during the assembly of the head of bacteriophage T4. Nature 227:680-685

12. Lowry OH, Rosebrough HJ, Farr AL, Randall RJ 1951 Protein measurement with the folin phenol reagent. J Biol Chem 193:265-275

13. Pasternack GR, Anderson RA, Leto TL, Marchesi VT 1985 Interactions between protein 4.1 and band 3 . An alternative binding site for an element of the membrane skeleton. J Biol Chem 260:3676-3683

14. Fukuda M, Eshbat Y, Tarone G, Marchesi VT 1978 Isolation and characterization of peptides derived from the cytoplasmic segment of band 3 , the predominate intrinsic membrane protein of the human erythrocyte. J Biol predom 253:2419-2428

15. Cuatrecasas P 1970 Protein purification by affinity chromatography. J Biol Chem 245:3059-3065

16. Hsu SM, Raine L 1981 Protein A, avidin, and biotin in immunohistochemistry. J Histochem Cytochem 29:1349-1353

17. Hazen-Martin DJ, Pasternack G, Spicer SS, Sens DA 1986 Immunolocalization of band 3 proteins in normal and cystic fibrosis skin. J Histochem Cytochem 24:823-826

18. Boucher RC, Ross DW, Knowles MR, Gatzy JT, Parker JC $1984 \mathrm{Cl}^{-}$permeabilities in red blood cells and peripheral blood lymphocytes from cystic fibrosis and control subjects. Pediatr Res 18:1336-1339

19. Levine DZ, Jacobson HR 1986 The regulation of renal acid secretion: new observations from studies of distal nephron segments. Kidney Int 29:10991109

20. Schwartz GJ, Al-Awqati Q 1985 Two functionally distinct types of mitochondrial-rich cells in cortical collecting tubule as determined by changes in cells $\mathrm{pH}$ in individually identified cells. Kidney Int 27:288 (abstr)

21. Verlander JW, Madsen KM, Tisher CC 1985 Two populations in intercalated cells exist in the cortical collecting duct of the rat. Clin Res 33:501 (abstr)

22. Drenckhahn D, Schluter K, Allen DP, Bennett V 1985 Colocalization of band 3 with ankyrin and spectrin at the basal membrane of intercalated cells in the rat kidney. Science 230:1287-1289 